INDEPENDENT JOURNAL OF MANAGEMENT \& PRODUCTION (IJM\&P)

http://www.ijmp.jor.br

v. 12, n. 8, November-December 2021

ISSN: 2236-269X

DOI: 10.14807/ijmp.v12i8.1453

\title{
EXPATRIATES' INTENTION TO SEND SURGICAL MASKS TO THEIR NATIVE COUNTRIES DURING THE COVID-19 PANDEMIC
}

Rushikesh Ulhas Khire

International Business Administration Program, Providence University, Taiwan

E-mail: rukhire@pu.edu.tw

Adam Edward Bell

International College, Providence University, Taiwan

E-mail: abell1018@yahoo.com

Schreiber Wiebke

International College, Providence University, Taiwan

E-mail: wiebke_schreiber@gmx.de

Chun Wang

International College, Providence University, Taiwan

E-mail: Vicentewang1009@gmail.com

Submission: 9/23/2020

Revision: $10 / 7 / 2020$

Accept: 12/1/2020

\section{ABSTRACT}

The main purpose of this study is to gain a better understanding of the factors that determine behavioral intention of expatiates living in Taiwan to send surgical masks to their native country following the Covid-19 outbreak. To achieve this, the study builds a research model by extending Theory of Reasoned Action (TRA) with Knowledge-Attitude-Behavior (KAB) and Risk perception conceptions, incorporating Covid-19 related factors such as knowledge, fear, and risk perception and situational factors such as perceived mask scarcity. An online questionnaire was administered with 83 respondents participating. A partial least squares structural equation modeling (PLS-SEM) analysis was used to evaluate the collected data. We found that no significant relationship between both Covid19 risk perception, and fear and expatiates' attitudes to send surgical masks back home. Results further reveal that Covid-19 knowledge is the only factor that significantly influence expatriates' attitudes, which in turn impact their on the intention to send surgical masks to their native countries. 
DOI: 10.14807/ijmp.v12i8.1453

Perceived mask scarcity found to positively moderate relationship between attitude and intention. This study contributes to the growing body of literature and research focused on the Covid-19 pandemic, and offers some implications for future research on the correlations between knowledge and scarcity in the context of the theory of reasoned action. Although the current study examines a contemporary critical issue, it presents a key example of personal protective equipment (PPE).

Keywords: Covid-19, Perceived scarcity, Risk perception, Surgical masks, Theory of Reasoned Action (TRA)

\section{INTRODUCTION}

In late 2019 pneumonia cases associated with an unknown coronavirus outbreak started growing in Wuhan, China. The disease outbreak started making headlines worldwide after Chinese scientists' announced the identification of the novel coronavirus and its genome in early January 2020 (Zhang et al., 2020). Since this virus was genetically related to Severe Acute Respiratory Syndrome (SARS), the International Committee on Taxonomy of Viruses (ICTV) named it "severe acute respiratory syndrome coronavirus 2 (SARS-CoV-2)" (Who1, 2020).

On February 11, 2020 the World Health Organization (WHO) named this disease COVID-19 and declared it as a global pandemic on March 11, 2020 (Ducharme, 2020; Who 2020). The WHO advised governments to encourage the public to wear surgical mask as a precautionary measure especially in places where social distancing is unavoidable $\left(\mathrm{Who}_{2}\right.$, 2020). Since surgical masks are fundamentally seen as a primary protection measure against Covid-19, governments of many countries made wearing surgical masks compulsory in public places.

Interestingly, in some countries (e.g., Qatar) not wearing a mask became a punishable offence and violators can be punished with heavy fines or imprisonment (Al-Monitor, 2020). People also consider surgical masks to be a primary form of personal protective equipment during the Covid-19 outbreak. As a result, demand for disposable masks spiked across the globe. Many countries including the US scrambled to satisfy the increasing demand of disposable surgical masks due to complex supply chains (Taplin, 2020).

Demand for surgical masks in the Western world before Covid-19 was much lower as the wearing of masks is not a culturally-rooted daily practice like in East Asia (Yang, 2014; Friedman, 2020). In fact, given the lower demand, most countries rely on East Asian 
DOI: 10.14807/ijmp.v12i8.1453

manufacturers and have limited or no face mask manufacturing capacity in country. As such, surgical mask scarcity became a severe concern due to increasing infection rates, consequent fear and simultaneous export restrictions.

Understanding the forthcoming global scarcity of surgical masks, Taiwan's government not only took restrictive actions by optimizing domestic consumption of masks and temporarily banning exports to other countries, but also started boosting domestic mask manufacturing capacity as an initial step. Taiwan managed to triple its overall surgical mask production capacity by the end of March, 2020 (Wang et al., 2020). Thereafter, the government initiated international donation of masks. Taiwan sent over 10 million surgical masks to the US and Europe in early April, 2020 (Peel \& Hille, 2020). Taiwan also sent masks to many other countries including the Philippines, Singapore, India, Japan and Australia, etc. (Strong, 2020). Interestingly, the government also lifted export restrictions and allowing each person in Taiwan to send a limited number of surgical masks to their close relatives living abroad via Chunghua post (Wu et al., 2020; Zhang, 2020) and private express delivery services like FedEx, DHL, UPS, etc. that were capable to handle express delivery in about 111 countries/territories across the globe including Canada, Italy, Germany, India, Australia, etc. (Shan, 2020). However, given that global logistics operations were severely affected due to Covid-19 and pertinent containment policies (Heiland \& Ulltveit-Moe, 2020; Fenton, 2020), this study attempts to conduct a hypothetical examination of factors affecting expatriates' intention to send surgical masks to their native countries during the Covid-19 pandamic.

Considering that many places around the globe have been hard hit by the pandemic, surgical masks as well as other forms of personal protective equipment (PPE) have been in short supply throughout in most parts of the world. As an example, the US Center for Disease Control and Prevention has deemed surgical masks to be critical supplies and recommends they should be reserved for healthcare workers and other medical first responders (CDC, 2020). Thus in the US, average citizens are recommended to wear cloth face coverings instead of surgical masks.

Because surgical mask supply in Taiwan has recently normalized and domestic inventory is sufficient, the Taiwan government has lifted export restrictions (Zhang, 2020) allowing people to send surgical masks overseas to family members and loved ones. As such many expatriates have taken advantage and begun purchasing and sending surgical masks abroad for the reasons mentioned above. 
DOI: 10.14807/ijmp.v12i8.1453

In addition to scarcity of surgical masks, people have been influenced by various factors such as fear and anxiety caused by news and social media channels, their level of knowledge on how to deal with Covid-19, risk perception (Cori et al, 2020), etc., therefore couriering surgical masks has become a great opportunity for expatriates living in Taiwan to help their friends and family members back home.

However, due to the novelty of this issue current literature focusing on expatriates' motivations to courier masks abroad is not readily available. Therefore, the main objective of this study is to investigate factors that drive intention of expatiates in Taiwan to send surgical masks to their native country during the Covid-19 outbreak. The second objective of this study is to determine factors that shape expatriates' attitudes to send surgical masks to their native country.

In order to achieve these objectives, we build a robust theoretical framework on the basis of the Theory of Reasoned Action (TRA) (Fishbein \& Ajzen, 1975; Ajzen \& Fishbein, 1980) and extended it by integrating Covid-19 related factors such as fear, level of knowledge, and risk perception. Factors based on Knowledge-Attitude-Behavior (KAB) (Bettinghaus, 1986; Zhu \& Deng, 2020) and Risk-perception related behavior (Hutjens, 2014; Gerhold, 2020) are also incorporated into the research model to reach the second objective.

In addition, this study examines the moderating effect of scarcity on expatriates' behavior. Data was collected through a questionnaire survey and analyzed by partial least squaring structural modeling modelling (PLS-SEM) technique. Among Covid-19 knowledge, fear and risk perception, Covid-19 knowledge was found to be the only meaningful factors that significantly shape expatriates' attitude and in turn their intention to send surgical masks to their native countries.

The results also suggest that perceived mask scarcity significantly moderates the relationship between attitude and intention. Overall, this study attempts to examine expatriates' behavioral intention during the early second half of the year 2020 in Taiwan, which is arguably an immediate post-covid-19 period on the island.

\section{THEORETICAL BACKGROUND AND HYPOTHESES DEVELOPMENT}

The Theory of Reasoned Action (Fishbein \& Ajzen, 1975; Ajzen \& Fishbein, 1980) suggests that behavioral intentions, which are defined as the immediate predecessors to behavior, are a function of pronounced information or beliefs about the likelihood regarding a specific outcome that performing a particular behavior will determine. Behavioral intention is 
DOI: 10.14807/ijmp.v12i8.1453

described as a central role in the model as an immediate factor of behavior. It is defined as the cause of two variables, i.e., (1) attitude toward the intended behavior, (2) subjective norms that represent the subject's assumptions or expectations on the outcome of their behavior as viewed by the people that are important to them. The theory further suggests that consumer behavioral intention is a function of attitude toward the behavior in question.

Attitude (Dillard \& Pfau, 2002) is defined as a response towards performing the intended behavior and does not include the attitudes towards one generalized object. It is further categorized as the likelihood of purchase depending on the positive or negative attitude the subject displays towards the product (Lobb et al., 2007). In this study attitude refers to the degree to which a consumer feels about surgical masks in order to protect their own health as well as others that are related to the individual, such as family and loved ones.

The pandemic has caused subsequent dramatic change in consumer behavior, such that consumers who have never purchased or worn a surgical mask are now struggling to obtain them. While Taiwan has been successful managing domestic Covid-19 cases and boosting surgical mask manufacturing, international news regarding uncontrolled outbreaks, lockdowns, rising rates of infections and surging death tolls has created panic worldwide including within expatriate circles in Taiwan.

To comprehend this, the current study applies Knowledge-Attitude-Behavior (KAB) (Bettinghaus, 1986; Zhu \& Deng, 2020) as well as Risk perception (Hutjens, 2014; Gerhold, 2020) for determining factors that shape expatriates' attitudes toward sending surgical masks to their native countries. Accordingly, this study considers the role of Covid-19 knowledge, perception of risk and fear in shaping attitudes. In this study Covid-19 knowledge is defined as the knowledge that expatriates have gained from various sources like newspapers, television, social media, etc. Fear relates to fear of getting physiological harm by Covid-19. Risk perception is given as the expatriates' intuitive judgements about impacts of Covid-19 on an individual.

The contemporary research regarding impacts of Covid-19 on consumer behavior is discrete but rapidly growing. Huynh (2020) investigated impacts of socio-economic factors and use of social-media on the Covid-19 risk perception in Vietnam and found that geographical regions and behaviors in using social media have a positive impact on the risk perception of COVID-19 epidemic in Vietnam.

Taghrir et al. (2020) developed a survey to assess relationship between Covid-19 related 
DOI: 10.14807/ijmp.v12i8.1453

knowledge, preventive behavioral practices and risk perception among Iranian medical students. Their results indicate that a negative but significant correlation between respondents' self-reported preventive behaviors and their risk perception. Iorfa et al. (2020) proposed a model for examining relationships between COVID-19 knowledge, risk perception and precautionary behavior among Nigerians.

They found that Covid-19 knowledge enhances higher involvement in precautionary behavior through risk perception in case of females but not males. Capone et al. (2020) investigated the relationships between information seeking, perceived risk and personal resources related to the academic context. They found that students with high levels of information seeking presented higher levels of well-being and risk perception. Addo et al. (2020), in an empirical study, found that Covid-19 fear strongly affects consumer purchase behavior of personal protective equipment. Gerhold (2020) explored Covid-19 risk perception in Germany and found that older people and women perceive higher Covid-19 risk than younger people and men, respectively.

Previous relevant literature has proven that several factors such as fear, risk perception (Zhou et al., 2016), and knowledge (Lei et al., 2019) are key factors that affect the behavioral intention. For instance, Hutjens (2014) examined how fear impacts buyer behavior during an animal disease outbreak, and found that both fear and risk perception significantly affect consumer intention to buy chicken meat. Lei et al. (2019), in an empirical study, investigated the impact of avian influenza knowledge on live poultry market workers' attitude and preventive practices.

They concluded that level of knowledge is one of the most critical factors that affect consumer attitudes toward control measures. Prior research related to consumer behavior in health sector evidenced that disease outbreaks are likely to create risk perceptions and emotional fear in consumers which ultimately affect their behavioral attitude (Hutjens, 2014). It also suggests that knowledge affects both risk perception (Wang et al., 2017) and fear (Boccia et al., 2018). In light of above arguments, we hypothesize,

- H1: Expatriates' fear affects their attitude towards sending surgical masks to their native countries.

- H2: Expatriates’ Covid-19 knowledge affects their attitude towards sending surgical masks to their native countries.

- H3: Expatriates’ risk perception affects their attitude towards sending surgical masks to 
DOI: 10.14807/ijmp.v12i8.1453

their native countries.

- H4: Expatriates' attitudes positively affect their intention to send surgical masks to their native countries.

Subjective norms, also known as social norms, are generally defined as a variable that is assessing an individual's motivation to follow the imposed norms of others (Ajzen \& Fishbein, 1980). The individual beliefs to behavioral expectations of a valued reference person or group are weighted by the subjective motivation to follow the assumed expectations. Therefore, the variable links the behavior of the subject in social relations to other individuals. In summary, the variable subjective norms are used to integrate the socialization process into predicting behavior (Ajzen \& Fishbein, 1980). Therefore, we hypothesize,

- H5: Subjective norms positively affect expatriates’ intention to send surgical masks to their native countries.

As mentioned, the theory of reasoned action (TRA) is restricted to voluntary behaviors. These prepositions severely restrict the behaviors the theory can be applied to. Ajzen and Fishbein (1980) addressed this discrepancy in their work about planned behavior, stating "every intended behavior is a goal where attainment is subject”. The degree of control can be influenced by factors including requisite knowledge and the necessary skills and abilities.

This research attempts to investigate expatriates' intentions to send surgical masks to their countries, it is necessary understand role of contemporary mask shortage. For the same reason, we further extended the framework by employing perceived mask scarcity as a moderating variable. Previous logistics related research have found a moderating effect of resource scarcity in various contexts.

For instance, Maghsoudia et al., (2018)'s research on 101 humanitarian organizations in the emerging countries within Southeast Asia found that resource scarcity meaningfully moderates relationship between resource sharing and performance outcomes. Regardless of cultures and national borders, each stage of the epidemic's escalation has quickly resulted in the affected population raiding shops, causing scarcity of surgical mask, toilet paper, and hand sanitizer. Understanding criticality and contemporary scarcity of mask during the pandemic is likely to exert social pressure on expatriates to courier masks. Overall, we argue that if the consumer perceived scarcity is higher, they are likely to experience a stronger attitude and social pressure to send masks to their loved once. 
DOI: 10.14807/ijmp.v12i8.1453

- H6: The higher the mask scarcity expatriates perceive the greater will be the impact of attitude on intention to send surgical masks to their native countries.

- H7: The higher the mask scarcity expatriates perceive the greater will be the impact of subjective norms on intention to send surgical masks to their native countries.

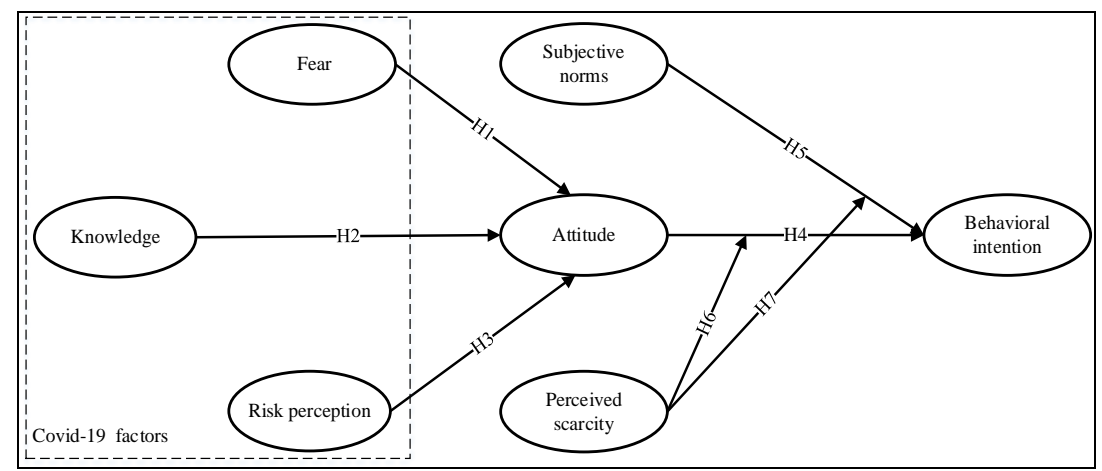

Figure 1: Research Framework

\section{METHODOLOGY}

\subsection{Sample and design}

An online questionnaire was developed to collect data from foreigners living in Taiwan. The questionnaire was developed comprising 20 items for seven constructs representing COVID-19 knowledge, fear, risk perception, perceived mask scarcity, attitudes, subjective norms, and behavioral intention. The constructs were each measured by an average of three items, and were measured using a 5-point Likert scale, with higher values corresponding to higher levels of agreement. In addition to the measurement items, we also included sociodemographic questions related to gender and age as well as nationality and length of stay in Taiwan. An additional question concerning the expected length of time the individual was planning to stay in Taiwan was also included. The demographic questions were listed at the end of the questionnaire. The questionnaire was distributed on online platforms such as Facebook.

\subsection{Demographics}

The socio-demographic profile of the survey participants showed that of the 83 respondents $51.3 \%$ were female, $47.4 \%$ were male and $1.3 \%$ preferred not disclose their gender. Regarding age, all but 1 respondent was over the age of 18 with the age bracket of 25 to 34 years being the largest (38.2\%). Questions regarding nationality and time spent in Taiwan were open questions. The majority of respondents indicated being from Germany (22.4\%) or the United States of America (21.1\%). 
DOI: 10.14807/ijmp.v12i8.1453

The remaining respondents hailed from all over the globe, with respondents from countries such Mongolia (2.9\%), Thailand (7.9\%), Guatemala (2.1\%), Canada (11.6\%), Kenya (2.3\%), Russia (3.5\%), Mexico (2.2\%), France (5.2\%), India (10.3\%), Indonesia (5.3), and the Netherlands (3.2\%) to name a few. Many respondents answered that they have lived in Taiwan for several months to several years, and the majority of respondents advised that they plan to continue living in Taiwan for 1 or more years, with some even saying they never plan to return to their native country.

\subsection{Construct Measurements}

Based on the Theory of Reasoned Action, the questionnaire contained measures for attitude, subjective norms, and behavioral intention. Measures including risk perception, fear, knowledge of COVID-19 as well as perceived mask scarcity were added to extend the model.

The two items used to measure attitude were adapted from prior research conducted by Ajzen and Fishbein (1980). The items were used to gauge the respondents' attitude towards sending masks home as well as their attitude towards masks made in Taiwan. The two items used to measure subjective norms were also adapted from prior research conducted by Ajzen and Fishbein (1980). The items were used to gauge the influence people considered important to the respondent had on the respondent concerning sending masks back home.

The two items used to measure behavioral intention were adapted from prior research conducted by Ajzen and Fishbein (1980). The items were used to gauge whether or not the respondent intended to send masks back home. The four items used to measure COVID-19 knowledge were adapted from prior research conducted by Lei et al. (2019) and Zhou et al. (2016). The items were used to gauge the respondents' general knowledge concerning COVID19. The three items used to Covid-19 measure risk perception were adapted from prior research conducted by Hutjens (2014).

The items were used to gauge respondents' risk perception concerning COVID-19 infections. The three items used to measure Covid-19 fear were adapted from prior research conducted by Hutjens (2014). The items were used to gauge the respondents' fear of becoming infected with COVID-19 or people they know becoming infected. The four items used to measure perceived mask scarcity were adapted from prior research conducted by Chen and Yao (2018). The items were used to gauge the respondents' feelings of concern and anxiousness concerning scarcity as well as their thoughts concerning the scarcity of masks back in their native country. 
INDEPENDENT JOURNAL OF MANAGEMENT \& PRODUCTION (IJM\&P)

http://www.ijmp.jor.br

v. 12, n. 8, November-December 2021

ISSN: 2236-269X

DOI: 10.14807/ijmp.v12i8.1453

Table 1: Scales

Item description Factor loading

\begin{tabular}{|c|c|c|}
\hline Variable & Item description & Factor loading \\
\hline \multicolumn{3}{|c|}{ Behavioral intention (BI) (AVE=0.95; CR=0.97; Cr. $\alpha=0.95)$ (Ajzen and Fishbein, 1980) } \\
\hline BI1 & $\begin{array}{l}\text { After reading all information, my intention is to buy masks to send to family and loved ones in } \\
\text { my native country. }\end{array}$ & 0.97 \\
\hline BI2 & I plan to send surgical masks to family/friends living in my native country as soon as possible & 0.97 \\
\hline \multicolumn{3}{|c|}{ Attitude (AT) (AVE=0.76; CR=0.87; Cr.o=0.77) (Ajzen and Fishbein, 1980) (Wang et al, 2013) } \\
\hline AT1 & Overall, sending surgical masks to my native country would be a good idea & 0.91 \\
\hline AT2 & Overall, sending surgical masks to my native country would be a wise choice & 0.84 \\
\hline \multicolumn{3}{|c|}{ Subjective norms (SN) (AVE=0.87; CR=0.93; Cr.a=0.86) (Ajzen and Fishbein, 1980) } \\
\hline SN1 & People who are important to me think that I should send surgical masks to my native country & 0.94 \\
\hline SN2 & People who influence my behavior think that I should send surgical masks to my native country & 0.93 \\
\hline \multicolumn{3}{|c|}{ Covid-19 Knowledge (KN) (AVE=0.56; CR=0.83; Cr. $\alpha=0.74)$ (Zhou et al, 2016; Lei et al., 2019) } \\
\hline KN1 & Fever, cough and sore throat are early symptoms of COVID-19 infection & 0.67 \\
\hline KN2 & Human to human transmission of COVID-19 viruses has been confirmed & 0.92 \\
\hline KN3 & COVID-19 has killed many people so far & 0.55 \\
\hline KN4 & Vaccine for COVID-19 is not yet available & 0.82 \\
\hline \multicolumn{3}{|c|}{ Covid-19 Risk perception (RP) (AVE=0.56; CR=0.78; Cr. $\alpha=0.77)$ (Hutjens, 2014) } \\
\hline RP1 & I perceive the risk of COVID-19 for me personally as... & 0.54 \\
\hline RP2 & I perceive the risk of COVID-19 for individual like me as... & 0.68 \\
\hline RP3 & I perceive the risk of COVID-19 for society in my native country in general as... & 0.96 \\
\hline \multicolumn{3}{|c|}{ Covid-19 Fear (FE) (AVE=0.70; CR=0.87; Cr. $\alpha=0.77)$ (Hutjens, 2014) } \\
\hline FE1 & My feeling of fear of the consequences of COVID-19 is... & 0.65 \\
\hline FE2 & $\begin{array}{l}\text { My feeling of fear of an immediate family member in my native country contracting COVID-19 } \\
\text { and becoming ill is... }\end{array}$ & 0.92 \\
\hline FE3 & $\begin{array}{l}\text { My feeling of fear of a close loved one in my native country contracting COVID-19 and } \\
\text { becoming ill is... }\end{array}$ & 0.92 \\
\hline \multicolumn{3}{|c|}{ Perceived mask scarcity (SC) (AVE=0.66; CR=0.88; Cr.a=0.83) (Chen and Yao, 2018) } \\
\hline SC1 & I am concerned about the limited quantity of surgical masks availability in my native country & 0.90 \\
\hline SC2 & I become anxious when I see "sold out" signs or news articles & 0.60 \\
\hline SC3 & $\begin{array}{l}\text { I feel that the limited supply of surgical masks in my native country will cause many people to } \\
\text { buy. }\end{array}$ & 0.80 \\
\hline SC4 & I think that the current supply of surgical masks in my native country is too small. & 0.91 \\
\hline
\end{tabular}

\subsection{Data Analysis}

Data analysis is conducted using a two-step approach. First, confirmatory factor analysis (CFA) is conducted to test reliability and validiaty of measurement items. Second, the conceptual framework model is tested using the (PLS-SEM) method in SmartPLS (v.3.3.2), where a bootstrap resampling of 5,000 subsamples is used to ensure stability of the results (Hair et al., 2012). We first used Cronbach's alpha $\alpha$ to determine internal factor reliabilty. All seven factors had a Cronbach's $\alpha$ greater than 0.70 , which indicates internal reliability of the factors is reasonable. We next performed confirmatory factor analysis using SmartPLS (v.3.3.2) (SmartPLS GmbH).

All measurement items were kept as they were all found to have factor loadings greater than 0.50. Item convergence was assessed through the average variance extracted (AVE) and construct reliability (CR). AVE and CR values were evaluted as suggested by Fornell and Larker (1981) and found to be greater than or equal to 0.50 and 0.70 . As such, the results indicate internal consistency of the measurement items included within their respective factors. Table 1 shows the scales along with the factor loadings, AVE and CR values of each construct. 
DOI: 10.14807/ijmp.v12i8.1453

The square root of the AVE was also calculated and shown to be higher that the correlation between variables, which indicates sufficient discriminant validity (Fornell \& Larcker, 1981). Based on the results the proposed conceptual model is considered to have sufficient convergent and descriminant validity as well as reliability, and the proposed conceptual model is believed to be satisfactory. Table 2 displays the discriminant value results.

PLS-SEM is generally preferred for smaller sample sizes and more complex models (Chin, 1998; Hair et al., 2012). It has shown to produce accurate path coefficient estimates even when the sample sizes are relatively small as 60 (Cyr et al., 2006), 93 (Sakka et al., 2013) and 100 (Mckenna et al., 2013). According to previous literature (Henseler et al., 2009), the minimum sample size using PLS-SEM technique should be larger than either 10 times the number of items of the most complex construct/formative construct or 10 times the largest number of structural paths directed at a particular construct in the inner path model. Referring to Table 3, the maximum number of paths directed to the construct behavioral intention are five and our sample size of 83 surpassed the minimum threshold of 50 .

It can be seen from Figure 2 that the largest number of directed paths toward the dependent variable, behavioral intention, or largest number of items of the most complicated construct (e.g., perceived mask scarcity, Covid-19 knowledge) are four therefore the sample size of 83 exceeds the required minimum sample size of 40 .

Table 2: Correlations Matrix

\begin{tabular}{|l|l|l|l|l|l|l|l|l|l|l|}
\hline & BI & RP & AT & FE & KN & SC & SN & $\sqrt{ }$ AVE & Mean & SD \\
\hline BI & 1.0 & & & & & & & 0.97 & 2.64 & 1.52 \\
\hline RP & 0.33 & 1.0 & & & & & & 0.76 & 2.73 & 1.19 \\
\hline AT & 0.58 & 0.25 & 1.0 & & & & & 0.87 & 3.81 & 1.21 \\
\hline FE & 0.28 & 0.54 & 0.26 & 1.0 & & & & 0.84 & 3.44 & 1.22 \\
\hline KN & 0.15 & 0.37 & 0.45 & 0.46 & 1.0 & & & 0.75 & 4.37 & 1.00 \\
\hline SC & 0.48 & 0.38 & 0.50 & 0.45 & 0.32 & 1.0 & & 0.82 & 3.15 & 1.36 \\
\hline SN & 0.60 & 0.24 & 0.26 & 0.21 & 0.08 & 0.25 & 1.0 & 0.94 & 2.03 & 1.29 \\
\hline
\end{tabular}

Notes: AVE- Average variance extracted, SD-Standard deviation,

BI-Behavioral intention, RP-Risk perception, AT-Attitude, FE-Fear, KN-Knowledge,

SN-Subjective norm, SC-Perceived scarcity

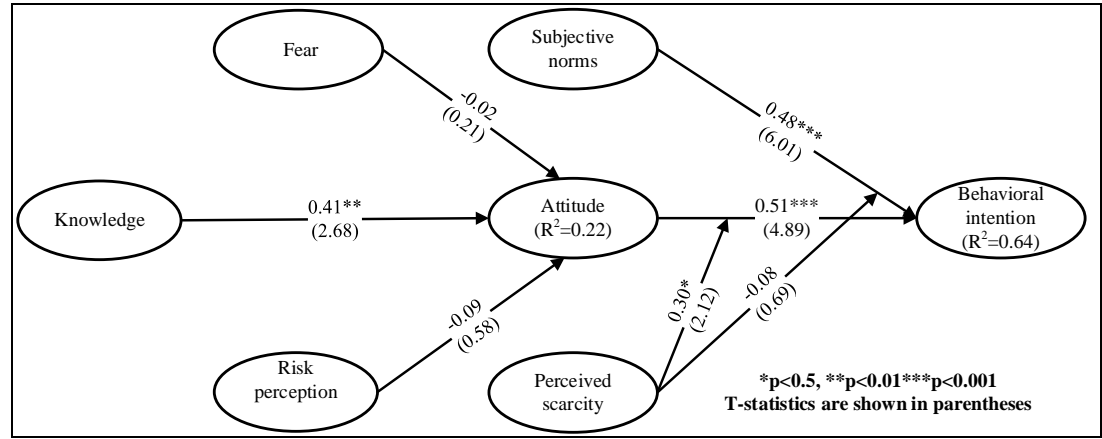


Figure 2: Structural model

Results of the structural model testing (Figure 2) show that all hypothesized relationships except H1, H3 and H7 were supported. Knowledge of COVID-19 is found to be only factor that affects expatriates' attitudes. The result also indicates an indirect significant impact of knowledge on behavioral intentions through attitude ( $b=0.21, p<0.05$ ). We found significant positive correlation between knowledge and Covid-19 risk perception $(\mathrm{p}<0.01)$ and fear $(p<0.01)$. Correlation between knowledge and fear was slightly higher than risk perception. Surprisingly, neither fear nor risk perception had any significant impact on attitudes. They also had no significant indirect impact on intention.

The result further suggests that perceived mask scarcity significantly moderates the relationship between attitude and intention but not the relationship between subjective norms and intention (Table 3). To further elucidate the interaction effect of perceived scarcity, we plotted an interactive effect graph Figure 3. In addition, following the theory of reasoned action, attitudes and subjective norms have also been shown through this research to have a significant positive effect on behavioral intention. The impact of attitude on expatriates' intention was stronger than that of subjective norms in the full model, i.e., model 3 (Table 3).

Table 3: Moderating effects of perceived scarcity on expatriates' behavioral intention

\begin{tabular}{|c|c|c|c|}
\hline Variables & Model 1 & Model 2 & Model 3 \\
\hline AT & $0.45^{* * *}$ & $0.37^{* * *}$ & $0.51^{* * *}$ \\
\hline SN & $0.49^{* * *}$ & $0.46^{* * *}$ & $0.48^{* * *}$ \\
\hline PS & - & $0.19^{*}$ & $0.19^{*}$ \\
\hline AT*PS & - & - & $0.30^{*}$ \\
\hline SN*PS & - & - & -0.08 \\
\hline \multicolumn{2}{|r|}{ Dependent variable= Behavioral intention } & $\mathrm{R}^{2}=0.59$ & $\mathrm{R}^{2}=0.64$ \\
\hline
\end{tabular}

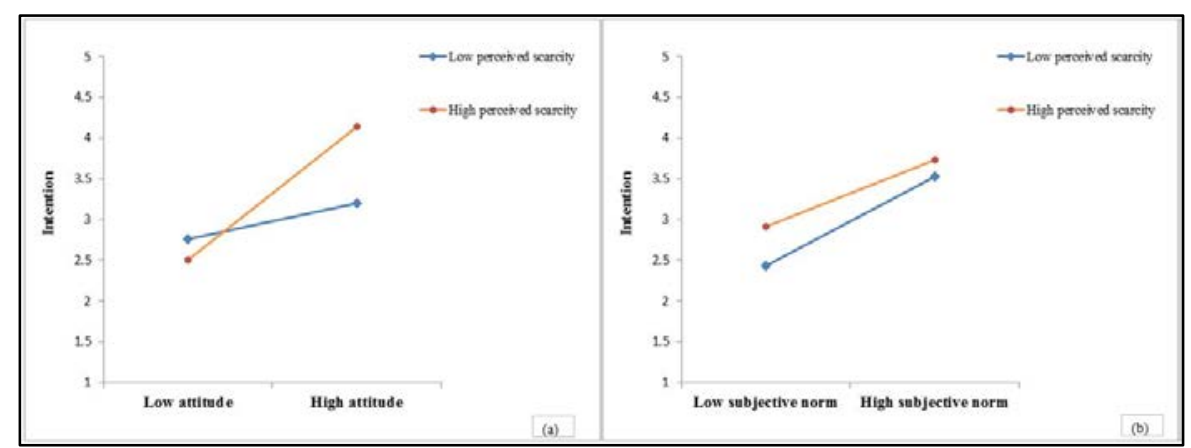

Figure 3: Interaction effect between perceived scarcity and attitude (a), and subjective norm (b)

\section{DISCUSSION AND CONCLUSION}

As far as we can tell, the influences of mask scarcity and Covid-19 knowledge have not been extensively researched in the context of surgical mask buying behavior, particularly in 
DOI: 10.14807/ijmp.v12i8.1453

expatriates residing in Taiwan. With this in mind, we have conducted a study to determine the driving factors that shape expatriates' attitudes and intentions to purchase and send surgical masks back home. We extended the Theory of Reasoned Action (TRA) with KnowledgeAttitude-Behavior (KAB) and Risk perception conceptions to incorporate Covid-19 factors such as fear, knowledge and risk perception to examine factors that shape expatriates' attitude and behavioral intention to send masks home. In addition, moderating effect of situational factors such as perceived mask scarcity was tested.

We discovered that the expatriates surveyed do intend to purchase surgical masks and send home, and this can be explained mainly through three key factors. The first is subjective norms. Expatriates living in Taiwan intend to send surgical masks due to the social pressure they experience. Most people that are important to those foreigners living in Taiwan or abroad think purchasing and sending masks back home is a positive behavior, which in turn may lead the individual to feel like it is an obligatory behavior to maintain social ties, and thus most expatriates intend to do so.

The second key factor driving expatriates to send masks home is their attitude towards this behavior. Most foreigners have a positive attitude towards sending masks home and view this behavior favorably. Attitudes in turn can be partially explained through the remaining two factors, namely the expatriates' knowledge of COVID-19 and their perception related to the scarcity of masks back in their native countries. Most expatriates possess knowledge of COVID-19 and understand that surgical masks can help prevent the spread. Perhaps this is why we found an indirect significant impact of knowledge of COVID-19 on intention, the third factor.

The final factor is the moderating effect of perceived scarcity. Expatriates also believe that their native countries do not have enough masks and thus perceived mask scarcity back home is a real concern. Figure 3 clearly shows that higher perception of scarcity strengthens the relationship between attitude and intention while it doesn't meaningfully affect relationship between subjective norms and behavioral intention.

Covid-19 knowledge was also found to have positive significant correlations with risk perception and fear. This finding is partially consistent with previous research (Scerri \& Scerri, 2017). Our overall knowledge about Covid-19 is largely objective and incomplete (Timsit, 2020). Moreover, while people are bombarded with excessive information by social media and television, finding complete, precise and factual knowledge from reliable sources is difficult. 
DOI: 10.14807/ijmp.v12i8.1453

Perhaps this is why the contemporary knowledge of Covid-19 has had a positive influence on both risk perception and fear.

Results further suggest that Covid-19 knowledge positively impacts expatriates' attitude. However, surprisingly, neither fear nor risk perception had any significant influence on expatriates living in Taiwan concerning their intention to purchase surgical masks to send home. Based on prior research (Hutjens, 2014), it seemed that both fear and risk perception would have a positive effect, but our research failed to find any significant relationships. One reason that fear and risk perception failed to shape attitude is perhaps due to the fact that the surveyed expatriates live in Taiwan, a country that has successfully controlled the outbreak and thus has never had to implement lock downs or other extreme measures. This could act to lower people's fear levels and perceptions of risk towards COVID-19.

Even though the study examines a contemporarily critical issue, it presents a key example of PPE and hence presents implications for both businesses and researchers. With regards to business, one such implication is that business owners abroad with loved ones in Taiwan can consider to leverage their relationships to setup micro-supply chains for PPE to compliment traditional wholesale export business models.

Expatriates living in Taiwan can assist their personal contacts back home in the acquisition of life-saving PPE products, such as surgical masks, when local supply gaps occur. Expatriates can also assist in acquiring PPE for their family which can in turn pass along surgical masks and other PPE to frontline health workers and medical staff. Surgical masks and other PPE can also be obtained by expatriates in Taiwan and shipped to organizations that help those that are more prone to be affected by pandemic such as woman, children and the elderly. That said, business owners and organizations can consider targeting expatriate social groups in Taiwan in order to seek out individuals that can assist in setting up these alternative supplychains.

While not the central focus of our questionnaire, another implication concerns the large number of migrant workers living in Taiwan that can also benefit from close access to Taiwan PPE manufacturers. They can leverage their situation and obtain PPE to send home to the loved ones in addition to the millions of dollars in remittances that they send home each year to countries like the Philippines, Vietnam, Indonesia and Thailand. As migrant workers often come from some of the more impoverished areas in their home countries, their sending of PPE ensures a greater chance that their loved ones and their communities can receive PPE whereas 
DOI: 10.14807/ijmp.v12i8.1453

they may not have otherwise had access.

\section{LIMITATIONS AND FUTURE RESEARCH}

There are a number of limitations that need to be taken into consideration. First it should be noted that the survey sampling size is relatively low, having only collected 83 completed questionnaires. While the pandamic is still ongoing, the future research should attempt to validate the findings of this study by collecting more surveys. Another limitation concerns the time in which the survey was administered. Had the survey been conducted earlier on in the pandemic when there was more uncertainty about the effects of the virus and its severity, this would probably have presented stronger feelings of risk and fear.

Secondly, it attempts to investigate expatriates’ willingness to send masks abroad, in a hypothetical setting therefore it fails to consider government policies and changes in government policies, and regulations regarding couriering surgical masks pertinent to expatriates. Future pertinent research should consider role of actual government policies for indepth examination.

Thirdly, the questionnaire was administered in English and distributed online through Facebook groups frequented by foreigners in Taiwan as well as being sent out electronically to foreign friends and associates living in Taiwan. It is thought that this method can inadvertently overlook non-English speaking foreigners as well as foreigners that are not technically savvy or present on social media. Future research should be considered at different stages within pandemic outbreaks, and similar studies can be administered in different languages to try and capture a larger demographic of foreigners living in Taiwan.

This study only concentrates on a few prominent factors such as Covid-19 fear, risk perception and knowledge that reform consumer attitudes regarding Covid-19. The future research may consider other factors such as consumer trust in government, healthcare infrastructure, WHO and other institutions. Moreover, future research should determine the impacts of consumer Covid-19 knowledge on other factors like Covid-19 fear and risk perception, etc.

\section{REFERENCES}

Addo, P. C., Jiaming, F., Kulbo, N. B., \& Liangqiang, L. (2020). COVID-19: fear appeal favoring purchase behavior towards personal protective equipment. The Service Industries Journal, 40(7-8), 471-490.

Ajzen, I., \&Fishbein, M. (1980). Understanding attitudes and predicting social behavior. Englewood Cliffs, NJ: Prentice-Hall. 
Al-Monitor (2020). Qatar to dole out $\mathbf{\$ 5 5 , 0 0 0}$ fines, jail time for not wearing face masks. Available: https://www.al-monitor.com/pulse/originals/2020/05/qatar-masks-coronavirusjail-fines-spike.html\#ixzz6Q5Aw4iU6

Bettinghaus, E. P. (1986). Health promotion and the knowledge-attitude-behavior continuum. Preventive medicine, 15(5), 475-491.

Boccia, F., Covino, D., \& Sarnacchiaro, P. (2018). Genetically modified food versus knowledge and fear: A Noumenic approach for consumer behaviour. Food research international, 111, 682-688.

Capone, V., Caso, D., Donizzetti, A. R., \& Procentese, F. (2020). University Student Mental Well-Being during COVID-19 Outbreak: What Are the Relationships between Information Seeking, Perceived Risk and Personal Resources Related to the Academic Context?. Sustainability, 12(17), 7039.

CDC (2020). Considerations for wearing cloth face coverings. Coronavirus disease 2019 (COVID-19). National Center for Immunization and Respiratory Diseases (NCIRD), Division of Viral Diseases. Available: https://www.cdc.gov/coronavirus/2019ncov/prevent-getting-sick/cloth-face-cover-guidance.html\#surgical-masks

Chen, C. C., \& Yao, J. Y. (2018). What drives impulse buying behaviors in a mobile auction? The perspective of the Stimulus-Organism-Response model. Telematics and Informatics, 35(5), 1249-1262.

Chin, W. W. (1998). The partial least squares approach to structural equation modeling. Modern methods for business research, 295(2), 295-336.

Cori, L., Bianchi, F., Cadum, F., \& Anthonj, C. (2020). Risk Perception and Covid-19. International Journal of Environmental research and public health, 17, 3114.

Costarelli, S., \& Colloca, A. P. (2007). The Moderation of Ambivalence on AttitudeIntention Relations as Mediated by Attitude Importance. European Journal of Social Psychology, 37, 923-933.

Cyr, D., Head, M., \& Ivanov, A. (2006). Design aesthetics leading to m-loyalty in mobile commerce. Information \& management, 43(8), 950-963.

Dillard, J. P., \& Pfau, M. (2002). The Persuasion Handbook (1. Aufl.).. Thousand Oaks, Kanada: SAGE Publications.

Ducharme, J. (2020). World Health Organization Declares COVID-19 a 'Pandemic.' Here's What That Means. Available: https://time.com/5791661/who-coronavirus-pandemicdeclaration/

Fenton, I. (2020). Coronavirus and aviation: Why is air cargo grounded when the world needs it most? Available: https://www.weforum.org/agenda/2020/04/coronavirus-aviationwhy-is-air-cargo-grounded-when-the-world-needs-it-most/

Fischbein, M., \& Ajzen, I. (1975). Belief, Attitude, Intention and Behavior: An introduction to Theory and Research. Reading, MA: Addison-Wesley

Fornell, C., \& Larcker, D. (1981). Evaluating Structural Equation Models with Unobservable Variables and Measurement Error. Journal of Marketing Research, 18(1), 39-50.

Friedman, U. (2020). Face Masks Are In. Available:

https://www.theatlantic.com/politics/archive/2020/04/america-asia-face-maskcoronavirus/609283/ 
Gerhold, L. (2020). COVID-19: Risk perception and Coping strategies. Available: https://psyarxiv.com/xmpk4

Hair, J., Sarstedt, M., Ringle, C., \& Mena, J. (2012). An Assessment of the Use of Partial Least Squares Structural Equation Modeling in Marketing Research. Journal of the Academy of Marketing Science, 40(3), 414-433.

Heiland, I., \& Ulltveit-Moe, K. (2020). An unintended crisis: COVID-19 restrictions hit sea transportation. VoxEU., Available: https://voxeu.org/article/covid-19-restrictions-hitsea-transportation

Henseler, J., Ringle, C. M., \& Sinkovics, R. R. (2009). The use of partial least squares path modeling in international marketing. Advances in international marketing, 20, 277-320.

Hutjens, M. (2014). The influence of fear on the buying behavior of consumers in case of an animal disease outbreak. Available: https://edepot.wur.nl/318026

Huynh, T. L. (2020). The COVID-19 risk perception: A survey on socioeconomics and media attention. Econ. Bull, 40(1), 758-764.

Iorfa, S. K., Ottu, I. F., Oguntayo, R., Ayandele, O., Kolawole, S. O., Gandi, J. C., \& Olapegba, P. O. (2020). COVID-19 knowledge, risk perception and precautionary behaviour among Nigerians: A moderated mediation approach.

Available: https://www.medrxiv.org/content/medrxiv/early/2020/05/26/2020.05.20.20104786 .full.pdf

Lei, X., Jing, S., Zeng, X., Lin, Y., Li, X., Xing, Q., \& Østbye, T. (2019). Knowledge, attitudes and practices towards avian influenza among live poultry market workers in Chongqing, China. Preventive veterinary medicine, 162, 151-159.

Lobb, A., Mazzocchi, M., \& Traill, W. (2007). Modelling risk perception and trust in food safety information within the theory of planned behaviour. Food Quality and Preference, 18(2), 384- 395.

Maghsoudi, A., Zailani, S., Ramayah, T., \& Pazirandeh, A. (2018). Coordination of efforts in disaster relief supply chains: the moderating role of resource scarcity and redundancy. International Journal of Logistics Research and Applications, 21(4), 407430.

Mckenna, B., Tuunanen, T., \& Gardner, L. (2013) Consumers’ adoption of information services. Information \& Management, 50(5), 248-257.

Peel, M., \& Hille, K. (2020). Taiwan to donate 10m masks to Europe and US. Available: https://www.ft.com/content/e47a8cf4-786d-4367-a589-054a6a198840

Sakka, O., Barki, H., \& Côté, L. (2013). Interactive and diagnostic uses of management control systems in IS projects: Antecedents and their impact on performance. Information \& Management, 50(6), 265-274.

Scerri, A., \& Scerri, C. (2017). Training older adults about Alzheimer's disease-impact on knowledge and fear. Educational Gerontology, 43(3), 117-127.

Shan, S. (2020). Virus Outbreak: Post office restates mask guidelines. Available: https://www.taipeitimes.com/News/taiwan/archives/2020/04/10/2003734352

Strong, M. (2020). Taiwan to donate 1 million face masks to New Southbound Policy countries. Available: https://www.taiwannews.com.tw/en/news/3911703 
Taghrir, M. H., Borazjani, R., \& Shiraly, R. (2020). COVID-19 and Iranian Medical Students; A Survey on Their Related-Knowledge, Preventive Behaviors and Risk Perception. Archives of Iranian medicine, 23(4), 249-254.

Taplin, N. (2020). Why the Richest Country on Earth Can't Get You a Face Mask. Available: https://www.wsj.com/articles/why-the-richest-country-on-earth-cant-get-you-aface-mask-11585741254

Timsit, A. (2020). The psychology of coronavirus fear-and how to manage it. Available: https://qz.com/1812664/the-psychology-of-coronavirus-fear-and-how-to-overcome-it/

Wang, J., Tao, J., Yang, C., Chu, M., \& Lam, H. (2017). A general framework incorporating knowledge, risk perception and practices to eliminate pesticide residues in food: A structural equation modelling analysis based on survey data of 986 Chinese farmers. Food Control, 80, 143-150.

Wang, Y., Wiegerinck, V., Krikke, H., \& Zhang, H. (2013). Understanding the purchase intention towards remanufactured product in closed-loop supply chains. International Journal of Physical Distribution \& Logistics Management, 43, 866-888.

Wang, C. Y., Chung, J. F. \& Mazzetta, M. (2020). How team of technicians is helping Taiwan triple mask production. Available: https://chinapost.nownews.com/202003241096087

World Health Organization $_{1}$ (2020). WHO Director-General's opening remarks at the media briefing on COVID-19 - 5 June 2020. Available:

https://www.who.int/dg/speeches/detail/who-director-general-s-opening-remarks-at-themedia-briefing-on-covid-19---5-june-2020

World Health Organization $_{2}$ (2020). Naming the coronavirus disease (COVID-19). and the virus that causes it. Available: https://www.who.int/emergencies/diseases/novel-coronavirus2019/technical-guidance/naming-the-coronavirus-disease-(covid-2019).-and-the-virus-thatcauses-it

Wu, P. W., Yu, H. H. \& Kao, E. (2020). New online system for sending masks to overseas relatives crashes. Available: https://chinapost.nownews.com/20200409-1141185

Yang, J. (2014). A quick history of why Asians wear surgical masks in public. Available: https://qz.com/299003/a-quick-history-of-why-asians-wear-surgical-masks-in-public/

Zhang, L. (2020). Taiwan: Government Lifts Mask Export Ban and Loosens COVID-19 Restrictions. Available: https://www.loc.gov/law/foreign-news/article/taiwan-governmentlifts-mask-export-ban-and-loosens-covid-19-restrictions/

Zhang, Y., Geng, X., Tan, Y., Li, Q., Xu, C., Xu, J., \& Wang, H. (2020). New understanding of the damage of SARS-CoV-2 infection outside the respiratory system. Biomedicine \& Pharmacotherapy, p. 110-195.

Zhou, L., Turvey, C. G., Hu, W., \& Ying, R. (2016). Fear and trust: How risk perceptions of avian influenza affect Chinese consumers' demand for chicken. China Economic Review, 40), 91-104.

Zhu, H., \& Deng, F. (2020). How to Influence Rural Tourism Intention by Risk Knowledge during COVID-19 Containment in China: Mediating Role of Risk Perception and Attitude. International Journal of Environmental Research and Public Health, 17(10), 3514. 